\title{
Determinants of Corporate Disclosure in Financial Statements: Evidence from Vietnamese Listed Firms
}

\author{
Le Long Hau ${ }^{1}$, Luu Chi Danh ${ }^{2}$ \\ ${ }^{1}$ College of Economics, Cantho University, Cantho City, Vietnam \\ Campus II, 3-2 street, Ninhkieu district, Cantho city, Vietnam \\ ${ }^{2}$ Van Lang University, Hochiminh City, Vietnam
}

\begin{abstract}
Using data of listed firms on Hochiminh Stock Exchange, the study examines determinants of corporate disclosure in financial statements. In line with the literature, the findingsshow that firm size, the use of financial leverage and the presence of supervision board have a positive influence on corporate disclosure. Furthermore, auditing firm (whether a Big4 or not) also plays an important role in the degree of information disclosure by firms.Contradicting to the literature, however state ownership and the proportion of nonexecutive members in director board show a negative relation to corporate disclosure level. These counter factscanbe explained by real situations of Vietnam over the studied period. Finally, the concurrent role between chair of director board and managing director reduces corporate disclosure degree, as predicted by the agency theory.
\end{abstract}

Keywords - Corporate disclosure, listed firms, Vietnam, signaling theory, agency theory .

\section{INTRODUCTION}

Corporate disclosure is very necessary and important for investors on the financial market. The more corporate disclosureis provided to the market, the less asymmetric information is between firmsand investors, and also between firms and other agents (government agencies, banks, business partners).This help to reduces agency problem. Corporate disclosure hence is an important factor that directly influences the decision making of market participants who mainly obtain information through firm'sfinancial statements. The obtaining and screening of corporate information is even more necessary for investors in an emerging stock market like Vietnam. However, the disclosure degreevaries among firms and its determinants havestill been an open question for both academics and practioners.

Many empirical studies on the determinants ofcorporate disclosurein financial statementshave been implemented for countries around the world (e.g., Patton and Zelenka,

www.jjaems.com

\section{whw.ilaems.com}

1997; Ahmed and Courtis, 1999; Owusu-Ansah, 1998; Bushman, Piotroski et al. Cheung, Connelly et al., 2006 ... ..). For Vietnam, research on this issue is also conducted, for example, Phuong and Phuong (2014). Nevertheless, this study is different from the previous ones in a number of aspects. Firstly, in this study, the effect of some factors that are not considered bythe other research is investigated (e.g.,fixed assets, sectors, corporate governance variables such as the size and composition of director board, management structure and board of supervisors). In addition, the sample in this study has a slightly larger number of observations than previous ones, which shows a better representation for Vietnamese listed firms.

The remainder of this study is structured as follows. In section 2, empirical studies on the issue are reviewed, while the methodology is presented in section 3. Section 4 shows empirical results of the study. Finally, conclusions and policy recommendations are shown in section 5 .

\section{LITERATURE SURVEY}

Examples of empirical research on the determinants of corporate disclosure for countries in the world can be seen as follows. Singhvi (1968) examines the factors influencing corporate disclosure of Indian companies in the period from 1963 to 1965 , including firm size, profit, marginal profit, auditing firm, management type and major shareholder number. The results show that size, management structureand major shareholder numberare statistically related to corporate disclosure, while the remaining variables are not correlated to corporate disclosure. Raffournier (1995) teststhe influence of size, financial leverage,profitability, ownership structure, internationalized degree, auditor's size, the fixed-asset-tototal-asset ratio and sector on disclosure of Swiss listed firms in 1991. Results show that only size and internationalized degrees play astatistically significant role in the company's disclosure policy. Patton and Zelenka (1997) find that auditing type, number of

Page | 474 
employees, status of listed securities and returns on equity show a significant effect on the corporate disclosure of joint-stock firms in Czech Republic. Owusu-Ansah (1998) points out that size, ownership structure, age, internationalized degree and profitability are significantly associated with disclosure of listed firms in Zimbabwe. For listed firms in Kenya in 1992-2001, Barako (2007) find that corporate governance features and corporate characteristics.In Vietnam, studies using different approaches, significantly influence corporate disclosure and data samples are also conducted. For example, Phuong and Phuong (2014) show that size, auditing firm, profitability, listing time and ownership of foreign shareholders are significantly related to the corporate disclosure of 99 listed firms on Hochi minh stock exchange in 2011.

\section{METHODOLOGY}

\subsection{Data}

The sample consists of 198 non-financial listed firms (accounting for approximately of $66 \%$ of the population). Data are obtained from the audited financial statements in 2013 of listed firms on the Ho Chi Minh stock exchange. Financialsare not included in the sample due to their particular characteristics, i.e they are subject to strict regulations and have a different accounting mechanism.

\subsection{Empirical specification:}

Dependent variable - corporate disclosure index:

Since firms produce the financial statements subject to Decision 16/2006, together with the Circular 210/2009BTC and 244/2009-BTC issued by Ministry of Finance of Vietnam, the list of corporate disclosure itemsis constructedbased on these legal documents. This study utilizes the approach by previous studies with some adjustments for current context of Vietnam.More specifically, all possible disclosure items from financial statements shown in notes to financial statement are taken.Hence, a checklist of maximum number of 120 disclosure items in the financial statements, comprising of both legally compulsory and voluntary disclosure items, is presented in table $1 .{ }^{1}$ Then the corporate disclosure index, measuring the corporate disclosure degree, is calculated by the ratio of number of disclosed items to the maximum number of disclosure items (e.g., Barako (2007)).

\footnotetext{
${ }^{1}$ The list of items is available upon request.
}

Table.1.Summary of corporate disclosure items in financial statements

\begin{tabular}{|l|l|}
\hline Contents & $\begin{array}{l}\text { Number of } \\
\text { items }\end{array}$ \\
\hline Items are related to balance sheet & 52 \\
\hline Items are related to income statement & 12 \\
\hline Items are related to cash flow statement & 6 \\
\hline $\begin{array}{l}\text { Items must be presented on notes to } \\
\text { financial statements as required by circular } \\
210 / 2009 / T T-B T C \text { issued by Ministry of } \\
\text { Finance }\end{array}$ & 13 \\
\hline $\begin{array}{l}\text { Items are indicated to notes to financial } \\
\text { statements itself }\end{array}$ & 37 \\
\hline Total & 120 \\
\hline
\end{tabular}

Corporate disclosure indexreads

$$
I_{j}=\frac{\sum_{i=1}^{n_{j}} X_{i j}}{n_{j}}
$$

in which: $I_{j}$ is disclosure of firm $j\left(0 \leq I_{j} \leq 1\right)$; $n_{j}$ shows the maximum number of disclosed items of firm $j\left(n_{j} \leq 120\right)$; $X_{i j}=1$ if item ioccurs and is released by firm, $X_{i j}=0$ if the item $i$ occurs but is unreleased by firm, $X_{i j}$ is not counted if item $\mathrm{i}$ does not occur; $\mathrm{X}_{\mathrm{ij}}$ comprises of both obligatory and disclosed items. All these items $\left(\mathrm{X}_{\mathrm{ij}}\right)$ are equally weighed summedin calculating corporate disclosure index $\mathrm{I}_{\mathrm{j}}$ to avoid biases in assigning weights to items due to subjective assessments.

Definition of all independent variables:

Based on the literature, this study investigates a number offactors which can be classified into two groups: corporate operating characteristics and corporate governance characteristics, (see, e.g., Hossainet al, 1994; Wallace vàNaser, 1995; Barako, 2007; PhươngvàPhương, 2014; Singhvi, 1968;Ahmed và Courtis,1999).All independent variables are definedas follows:

+ Variables proxy for corporate operating characteristics:

SIZE (Billion VND) - Corporate size: defined as logarithm of total sales

QRATIO (Times) - Quick ratio: defined as [short-term assets - inventories] divided by short-term debts.

PROFIT (\%) - Profitability: defined as net profits divided by total sales

DEBT (Times) - Debt ratio: defined as total debts divided by owner's equity

FASSETS (\%) - Fixed assets: defined as [fixed assets accumulated depreciation] divided by total assets

BIG4 - Audit firm: Equal to 1 if firm is audited by a Big4auditing firm, and equal to 0 otherwise

LTIME (Years) - Listing time: defined as the time period from listing year up to year of 2013 
SECTOR - Sectors: Equal to 1 if firm is inmanufacturing sector, and equal to 0 otherwise

FOREIGN (\%) - Foreign ownership: defined as foreignerowned shares divided by total shares

STATE (\%) - State ownership: defined as state-owned shares divided by total shares

+ Variables proxy for corporate governance characteristics:

BOARDSIZE (people) - Director board size: defined as number of members in director board

BOARDCOMP (\%) - Director board composition: defined as number of non-executive director members divided by total number of members in director board
DUALITY - Chairperson of director board takes dual positions: Equal to 1 if firm's chairman of director board is concurrent the general director, and equal to 0 otherwise

SUPERV - Supervision board: Equal to 1 if firm has a supervision board, and equal to 0 otherwise

\subsection{Estimation method}

The regression specification is estimated using OLS method. In addition, the tests to check for reliability of the regression resultsare also performed such as multicollinearity (variance inflation factor (VIF)),heteroschedasticity (White test) and autocorrelation (Lagrange (LM)).

\section{EMPIRICAL RESULTS}

\subsection{Correlation matrix between variables and summary statistics of variables}

The correlation matrix between variables is presented in table 2, while table 3 shows the summary statistics of all variables. As can be seen from Table 2, the correlation between variables is fairly small (almost less than 0.4), therefore the possible effects of multi-collinearity in OLS regressions are negligible. Yet, a statistical check via VIF test is sobering.

\begin{tabular}{|c|c|c|c|c|c|c|c|c|c|c|c|c|c|c|}
\hline \multicolumn{15}{|c|}{ Table.2: Correlation matrix between variables } \\
\hline & $\begin{array}{l}\text { SIZ } \\
\text { E }\end{array}$ & $\begin{array}{l}\text { QRA } \\
\text { TIO }\end{array}$ & $\begin{array}{l}\text { PRO } \\
\text { FIT }\end{array}$ & $\begin{array}{l}\text { DE } \\
\text { BT }\end{array}$ & $\begin{array}{l}\text { FASS } \\
\text { ETS }\end{array}$ & $\begin{array}{l}\text { BIG } \\
4\end{array}$ & $\begin{array}{l}\text { LTI } \\
\text { ME }\end{array}$ & $\begin{array}{l}\text { SECT } \\
\text { OR }\end{array}$ & $\begin{array}{l}\text { FORE } \\
\text { IGN }\end{array}$ & $\begin{array}{l}\text { STA } \\
\text { TE }\end{array}$ & $\begin{array}{l}\text { BOARD } \\
\text { SIZE }\end{array}$ & $\begin{array}{l}\text { BOARD } \\
\text { COMP }\end{array}$ & $\begin{array}{l}\text { DUAL } \\
\text { ITY }\end{array}$ & $\begin{array}{l}\text { SUPE } \\
\text { RV }\end{array}$ \\
\hline SIZE & 1 & & & & & & & & & & & & & \\
\hline QRATIO & $\begin{array}{l}- \\
0.31 \\
70\end{array}$ & 1 & & & & & & & & & & & & \\
\hline PROFIT & $\begin{array}{l}0.16 \\
72\end{array}$ & $\begin{array}{l}0.147 \\
2\end{array}$ & 1 & & & & & & & & & & & \\
\hline DEBT & $\begin{array}{l}0.21 \\
24\end{array}$ & $\begin{array}{l}- \\
0.220 \\
6\end{array}$ & $\begin{array}{l}- \\
0.20 \\
83\end{array}$ & 1 & & & & & & & & & & \\
\hline $\begin{array}{l}\text { FASSET } \\
\text { S }\end{array}$ & $\begin{array}{l}0.06 \\
52\end{array}$ & $\begin{array}{l}- \\
0.184 \\
3\end{array}$ & $\begin{array}{l}0.00 \\
74\end{array}$ & $\begin{array}{l}- \\
0.02 \\
61\end{array}$ & 1 & & & & & & & & & \\
\hline BIG4 & $\begin{array}{l}0.36 \\
43\end{array}$ & $\begin{array}{l}- \\
0.035 \\
8\end{array}$ & $\begin{array}{l}0.01 \\
85\end{array}$ & $\begin{array}{l}- \\
0.10 \\
25\end{array}$ & $\begin{array}{l}- \\
0.092 \\
7\end{array}$ & 1 & & & & & & & & \\
\hline LTIME & $\begin{array}{l}0.15 \\
08\end{array}$ & $\begin{array}{l}- \\
0.136 \\
0\end{array}$ & $\begin{array}{l}0.12 \\
09\end{array}$ & $\begin{array}{l}- \\
0.13 \\
55\end{array}$ & $\begin{array}{l}0.026 \\
6\end{array}$ & $\begin{array}{l}0.05 \\
41\end{array}$ & 1 & & & & & & & \\
\hline SECTOR & $\begin{array}{l}0.31 \\
73\end{array}$ & $\begin{array}{l}- \\
0.144 \\
2\end{array}$ & $\begin{array}{l}0.04 \\
63\end{array}$ & $\begin{array}{l}- \\
0.03 \\
99\end{array}$ & $\begin{array}{l}0.180 \\
9\end{array}$ & $\begin{array}{l}0.13 \\
36\end{array}$ & $\begin{array}{l}0.18 \\
13\end{array}$ & 1 & & & & & & \\
\hline $\begin{array}{l}\text { FOREIG } \\
\mathrm{N}\end{array}$ & $\begin{array}{l}0.20 \\
84\end{array}$ & $\begin{array}{l}0.186 \\
6\end{array}$ & $\begin{array}{l}0.10 \\
55\end{array}$ & $\begin{array}{l}- \\
0.24 \\
97\end{array}$ & $\begin{array}{l}0.011 \\
8\end{array}$ & $\begin{array}{l}0.41 \\
92\end{array}$ & $\begin{array}{l}0.22 \\
85\end{array}$ & $\begin{array}{l}- \\
0.001 \\
2\end{array}$ & 1 & & & & & \\
\hline STATE & $\begin{array}{l}0.02 \\
11\end{array}$ & $\begin{array}{l}0.001 \\
7\end{array}$ & $\begin{array}{l}0.12 \\
79\end{array}$ & $\begin{array}{l}- \\
0.05 \\
24\end{array}$ & $\begin{array}{l}0.165 \\
4\end{array}$ & $\begin{array}{l}- \\
0.07 \\
36\end{array}$ & $\begin{array}{l}- \\
0.03 \\
86\end{array}$ & $\begin{array}{l}0.024 \\
4\end{array}$ & $\begin{array}{l}- \\
0.1292\end{array}$ & 1 & & & & \\
\hline $\begin{array}{l}\text { BOARDS } \\
\text { IZE }\end{array}$ & $\begin{array}{l}0.11 \\
83\end{array}$ & $\begin{array}{l}0.101 \\
7\end{array}$ & $\begin{array}{l}0.21 \\
34\end{array}$ & $\begin{array}{l}- \\
0.10 \\
05\end{array}$ & $\begin{array}{l}- \\
0.015 \\
6 \\
\end{array}$ & $\begin{array}{l}0.23 \\
85\end{array}$ & $\begin{array}{l}0.12 \\
65\end{array}$ & $\begin{array}{l}0.070 \\
5\end{array}$ & 0.3202 & $\begin{array}{l}- \\
0.15 \\
36 \\
\end{array}$ & 1 & & & \\
\hline $\begin{array}{l}\text { BOARD } \\
\text { COMP }\end{array}$ & $\begin{array}{l}0.01 \\
06\end{array}$ & $\begin{array}{l}0.038 \\
0\end{array}$ & $\begin{array}{l}0.16 \\
22\end{array}$ & $\begin{array}{l}- \\
0.17 \\
27\end{array}$ & $\begin{array}{l}- \\
0.026 \\
9 \\
\end{array}$ & $\begin{array}{l}0.13 \\
11\end{array}$ & $\begin{array}{l}0.10 \\
17\end{array}$ & $\begin{array}{l}0.048 \\
3\end{array}$ & 0.1727 & $\begin{array}{l}- \\
0.05 \\
86\end{array}$ & 0.2287 & 1 & & \\
\hline $\begin{array}{l}\text { DUALIT } \\
\text { Y }\end{array}$ & $\begin{array}{l}- \\
0.05 \\
53\end{array}$ & $\begin{array}{l}- \\
0.055 \\
0\end{array}$ & $\begin{array}{l}- \\
0.14 \\
97\end{array}$ & $\begin{array}{l}0.04 \\
67\end{array}$ & $\begin{array}{l}- \\
0.058 \\
9\end{array}$ & $\begin{array}{l}- \\
0.09 \\
42\end{array}$ & $\begin{array}{l}- \\
0.04 \\
20\end{array}$ & $\begin{array}{l}- \\
0.028 \\
3\end{array}$ & $\begin{array}{l}- \\
0.1034\end{array}$ & $\begin{array}{l}- \\
0.19 \\
41\end{array}$ & -0.1538 & -0.4493 & 1 & \\
\hline SUPERV & $\begin{array}{l}- \\
0.06 \\
82\end{array}$ & $\begin{array}{l}0.032 \\
7\end{array}$ & $\begin{array}{l}0.00 \\
53\end{array}$ & $\begin{array}{l}- \\
0.02 \\
04\end{array}$ & $\begin{array}{l}0.007 \\
8\end{array}$ & $\begin{array}{l}- \\
0.09 \\
08\end{array}$ & $\begin{array}{l}0.12 \\
89\end{array}$ & $\begin{array}{l}- \\
0.056 \\
7\end{array}$ & $-\overline{0.1460}$ & $\begin{array}{l}0.12 \\
31\end{array}$ & -0.1115 & -0.0422 & $\overline{-}-0152$ & 1 \\
\hline
\end{tabular}


Table.3: shows the summary statistics for all variables. In general, since no outliers in data can be observed, OLS estimation is appropriate. Then it is safe to go further with all estimations.

Table.3. Summary statistics of all variables

\begin{tabular}{|l|r|r|r|r|}
\hline \multicolumn{1}{|c|}{ Variables } & \multicolumn{1}{c|}{ Min } & \multicolumn{1}{c|}{ Max } & Mean & \multicolumn{1}{c|}{ S.D } \\
\hline SIZE (Billion VND) & 13.43 & 31.58 & 1.90 & 3.91 \\
\hline QRATIO (Times) & 0.29 & 17.57 & 2.11 & 2.05 \\
\hline PROFIT $(\%)$ & -45.40 & 44.30 & 4.00 & 22.10 \\
\hline DEBT (Times) & 0.03 & 27.98 & 1.75 & 2.62 \\
\hline FASSETS (\%) & 2.00 & 89.10 & 22.30 & 17.90 \\
\hline LTIME (Years) & 1.00 & 13.00 & 4.96 & 2.571 \\
\hline FOREIGN $(\%)$ & 0.00 & 49.00 & 14.80 & 16.40 \\
\hline STATE (\%) & 0.00 & 79.70 & 17.80 & 22.80 \\
\hline BOARDSIZE (people) & 4.00 & 11.00 & 6.53 & 1.69 \\
\hline BOARDCOMP (\%) & 0.00 & 100.00 & 63.90 & 17.20 \\
\hline
\end{tabular}

\subsection{Findings}

The regression results are presented in table 4 . The value of VIF for all independent variables is much smaller than 10 (i.e. even smaller than 2), confirming that multicollinearity is not problematic. Moreover, Lagrange (LM) test cannot reject the null hypothesis that no autocorrelation in the error terms of the model ( $p$-value $=$ 0.5432). Likewise, White test also shows the absence of heteroschedasticity in the model $(p$-value $=0.6565){ }^{2}$

From table 4 , it can be seen that the coefficient of SIZE, $D E B T, A U D I T$ and SUPERV is positive and statistically significant at the 5\% level. However, the coefficient of STATE, BOARDCOMP and DUALITY is statistically negatively at the significance level of $10 \%$, except for STATE at the $5 \%$ level of significance. These findings can be further discussed as follows.

Firstly, regression results show that corporate size (SIZE) has a positive effect on its disclosure, implying that the higher the sales, the more information firm discloses in the financial statements. This is consistent with most previous empirical studies, such as Raffournier, 1995; Patton and Zelenka, 1997; Ahmed and Courtis, 1999; Owusu-Ansah, 1998; Phuong and Phuong, 2014, ...), and also in accordance with the agency theory and signaling theory. In fact, an increase in sales can be considered as a positive message about its businessesthat firm wants to send to shareholders and other outsiders. This is especially true for the real situations in Vietnam over the studied period, where the Vietnamese economy has been facing severe difficulties, and many firms have been dissolved and bankrupted. Given these circumstances, more good information (e.g., sales increases) is needed to disclose in attempts to increase the confidence of investors and credit institutions.
Table.4: Regression results

Dependent variable:Corporate disclosure index $\left(I_{j}\right)$

\begin{tabular}{lccc}
\hline $\begin{array}{l}\text { Independent } \\
\text { variables }\end{array}$ & Coefficients & Std. & VIF \\
\hline Constant & $0.670^{* * *}$ & 0.085 & \\
SIZE & $0.008^{* *}$ & 0.004 & 1.688 \\
QRATIO & -0.001 & 0.002 & 1.371 \\
PROFIT & 0.007 & 0.021 & 1.241 \\
DEBT & $0.004^{* *}$ & 0.002 & 1.320 \\
FASSETS & -0.018 & 0.025 & 1.137 \\
BIG4 & $0.052^{* * *}$ & 0.012 & 1.453 \\
LTIME & 0.002 & 0.002 & 1.218 \\
SECTOR & -0.010 & 0.010 & 1.223 \\
FOREIGN & -0.033 & 0.033 & 1.627 \\
STATE & $-0.034^{*}$ & 0.020 & 1.184 \\
BOARDSIZE & 0.003 & 0.003 & 1.251 \\
BOARDCOMP & $-0.087^{* * *}$ & 0.029 & 1.381 \\
DUALITY & $-0.018^{*}$ & 0.010 & 1.368 \\
SUPERV & $0.043^{* * *}$ & 0.010 & 1.089 \\
\hline No. of observations & & 198 & \\
$R^{2}$ & & 0.310 & \\
Adjusted- ${ }^{2}$ & & 0.257 & \\
F-statistic & & 5.866 & \\
Prob(F-statistic) $_{\text {Durbin-Watson }}$ & & 0.000 & \\
\hline Notes: & & 1.991 & \\
\hline
\end{tabular}

Notes: *, ** and *** denote the significance levels of $10 \%, 5 \%$ and $1 \%$, respectively. 
As for debt ratio $(D E B T)$, the results show that firmwitha higher financial leverage tends to disclose more information, since as firm utilizes more debt the executives voluntarily disclose more information to increase its position to creditors, as well as to meet the information requirements by creditors. This is applicable with the current context of Vietnam, in which the use of excessive leverage by many firms have leaded to higher risk of insolvency and bankruptcies. Hence, the corporate disclosurehas become a way to show firm's trust worthy to creditors. This result is in line withsome others, e.g., Ahmed and Courtis, 1999; Barako, 2007, and is also consistent with the signaling theory.For auditing firm (AUDIT), it is obvious that firm audited by one of the Big4-auditorshas a higher corporate disclosure degree than the others. This shows a clear distinction between the quality of a Big4-auditor and that of other auditors from the perspectives of market participants in the country. As audited by a member of Big4-auditors, firm seems to bemore confident and ready to publish a greater amount of detailed information to outsiders. This finding is supported by previous research, (e.g., Patton and Zelenka, 1997; Barako, 2007; Wang, Sewon et al., 2008). In line with Ho and Wong (2001), results show that the presence of supervision board (SUPERV) has a positive influence on the corporate disclosure degrees. Since the supervision board is responsible for overseeing the board of directors and managing director in implementing their due roles, its existence is considered as a means to guarantee for the credibility of financial statements to outsiders (Bradbury, 1990). However, contradicting to previous studies, results for state ownership (STATE) in this study indicate that firm with higher state-owned shares disclose less information on financial statements than the others. Although being contrast to other previous studies, this finding isreasonable in the context of Vietnam. In Vietnam, there historically exists a common belief that state-dominated firms are problematic. Many statedominated firms suffered severely from a number of problems such as poor performance, bad corporate governance practices and disclosure of corruption by managers who are also governmental officials. E.g., in 2014, more than 400 state-owned firms were bankrupted and dissolved, namely bankruptcy of 92 enterprises anddissolvent of $313 .{ }^{3}$ Therefore, the presence of state ownership in firm does not necessarily mean an increase in the corporate disclosure level. Surprisingly, the coefficient of director board composition $(B O A R D C O M P)$ shows a significantly negative sign,

${ }^{3}$ http://kinhdoanh.vnexpress.net/tin-tuc/doanhnghiep/giai-the-pha-san-hon-400-doanh-nghiep-nhanuoc-2931637.html (Accessed on May, $5^{\text {th }}$ 2017) www.ijaems.com indicating that firm with a higher proportion of nonexecutive members to total number of director board tends to have a higher corporate disclosure degree. This is counter evidence against the agency theory, proposing that members of director board should not take any executive role in the firm. Nevertheless, this opposite effect (but is in line with Barako (2007)), may be explained by the fact that a high proportion of nonexecutive board member in director board may imply a high number of managing executive members from outside the firm. In an emerging market like Vietnam, these outside executives tend to limit the corporate disclosure as a way to protect firm's businesses from its competitors, which helps them to secure their positions in the firm. As expected, the findings from dual role of director board's chairperson (DUALITY) point out that if a company has a concurrent duty between chairperson and general director, the corporate disclosure degreeis reduced. In fact, as argued by the agency theory this dual role can easily lead to power concentration, resulting in possible manipulations of corporate financial activities, as well as restrictions on information disclosure by firms.

The coefficient of all other independent variables including QRATIO, PROFIT, FASSETS, LTIME, SECTOR, FOREIGN and BOARDSIZEis not statistically significant at the traditional significance levels. Therefore, the statistical evidence about the influences of these factors on the corporate disclosure cannot be found in this study.

\section{CONCLUSIONS AND POLICY RECOMMENDATIONS}

Due to the great importance of corporate disclosure on the financial statements, many empirical studies have been implemented for countries around the world. This study investigates the determinants of corporate disclosure in Vietnamese listed firms. Several findings from the study can be summarized. Regression results show that as predicted by the literature firm size, the use of financial leverage and the presence of supervision board have a positive effect on the corporate disclosure degree. Moreover, firm audited by a member of Big4 group tends to disclose more information than the others. However, contradicting to the literature, those factors comprising of state ownership and the proportion of non-executive members in director board show a negative effect on corporate disclosure.This counterevidence can be explained by real situations in Vietnam. Finally, thisstudy also supports the literature with the finding that firm with the concurrent role between chair of director board and managing director disclose less information than the others.

\section{whwifaems.com}


A number of recommendations have been put forward.Firstly, policy makers should pay more attention tothe quality of auditing firmsappointed to check financial statements of listed firms, since market participants seem to distinguish between financial statements audited by a Big4 and those audited by other auditing firms.Besides, stricter supervision rules should be considered on the structure of corporate management to improve the information disclosure quality by firms.

\section{REFERENCES}

[1] Adina, P. và P. Ion (2008). "Aspects Regarding Corporate Mandatory and Voluntary Disclosure". The Journal of the Faculty of Economics -Economic. University of Oradea, Vol. 3, pp 1407-1411.

[2] Ahmed, K. và J. K. Courtis (1999). “Associations between corporate characteristics and disclosure levels in annual reports: Amets-analvis".British Accounting Review. Vol. 31: pp. 35-61.

[3] Ahmed, K. and D. Nicholls (1994). "The Impact of Non-financial Company Characteristics on Mandatory Compliance in Developing Countries: The Case of Bangladesh". The International Journal ofAccounting. Vol. 29(1): pp 60-77.

[4] Alsaeed, K. (2006). "The association between firmspecific charateristicsanh disclosure: The case of Saudi Arabia". Journal of American Academyof Business Cambridge. Vol. 7(1): pp 310-321.

[5] Barako, D. G., P. Hancock, et al. (2006). "Factors Influencing Voluntary Corporate Disclosure by Kenyan Companies. "Corporate Governance: An International Review Vol. 14(2): pp 107-125.

[6] Barako, D. G. (2007). "Determinants of voluntary disclosure in Kenyan companies annual reports".African Journal of Businessmanagement, Vol. 1(5): pp 113-128.

[7] Bushman, R. M., J. D. Piotroski, et al. (2003). "What Determines Corporate Transparency?" Journal of Accounting Research Vol. 42(2): pp 207-252.

[8] Beyer, A. và I. Guttman (2010). "Voluntary Disclosure, Disclosure Bias and Real Effects". Stanford University Press, Feb. 2010.

[9] Bradbury, ME. (1990). "The incentives for voluntary audit committee formation”. J. Account. Public Policy. Vol. 9(1): pp 19-36.

[10]Chen, C. và M. Courtenay (2006). "Board Composition, Regulatory Regime and Voluntary Disclosure”. The International Journal ofAccounting, Vol. 41: pp 262-289.

[11]Chen, C. và B. Jaggi (2000). “Association Between Independent Non- Excutive Directions, Family control anh Financial Disclosure in Hongkong”. Journal of Accountinganh Public Policy, Vol. 19: pp 285-310.

[12] Cheung, S. Y.-L., J. T. Connelly, et al. (2006). "Determinants of Corporate Disclosure and Transparency: Evidence from Hong Kong and Thailand". Research Paper.Sasin Graduate Institute of Business Administration of Chulalongkorn University.

[13] Cooke, T. E. (1989). "Disclosure in the Corporate Annual Report of Swedish companies”. Accounting and Business Research, Vol. 19: pp 113.

[14]Cooke, T. E. (1991). "An Empirical Study of financial disclosure by Swedish companies”. Galand Pub, Newyork.

[15] Cooke, T. E. (1992). "The impact of size, Stock Market Listing and Industry Type on Disclosure in the Annual Reports of Janpanese Listed Corporations". Accounting and Business Research, Vol. 22: pp. 229.

[16] Firth, M. (1979). “Impact of size, stock market listing and auditors on voluntary disclosure in corporate annual reports". Accounting andBusiness Research, Vol. 9: pp. 273.

[17] Garcia-Meca, E. và I. Martinez (2005). “Assessing the quality of disclosure of disclosure on intangibles in the Spanish capital market".European Business Review, Vol. 17 (4): pp. 305-313.

[18]Gigler, F. (1994). "Self-enforcing voluntary disclosure”, Journal of Accounting Research Vol. 32: pp. 224-241.

[19] Giner, B. (1997). "The influence of company charateristicsanh accounting regulation on information disclosure by Spanish firms". European Accountin Review, Vol. 6 (1): pp. 45-68.

[20] Gelinas, U. J., R. B. Dull, et al. (2012). “Accounting Information Systems", 7th Edition (744 Pages Hardcover).

[21]Haniffa, R. M. và T. E. Cooke (2002). "Culture, corporate governance and disclosure in Malaysian corporations”, ABACUS, Vol. 38 (3): pp. 317-349.

[22] Healy, P. và K. Papelu (2001). "Information asymmetry, corporate disclosure, and the capital market: A review of the empirical disclosure literature". Journal af Accounting and Economics.

[23]Ho, S. S. M. and K. Shun Wong (2001). "A study of the relationship between corporate governance structures and the extent of voluntary disclosure."Journal of International Accounting, Auditing and Taxation 10(2): pp. 139-156.

[24]Hossain, M., L. M. Tan, et al. (1994). "Voluntary disclosure in an emerging capital market: Some 
empirical evidence from companies listed on the Kuala Lumpur Stock Exchange”. The International journalof Accounting, Vol. 29: pp. 334-351.

[25] Jensen, M. C. và W. H. Meckling (1976). "Theory of the firm: Managerial behavior, agency costs and ownership structure." Journal of Financial Economics Vol. 3(4): pp 305-360.

[26] Lakhal, F. (2003). "Voluntary earning Disclosures and Corporate Governance: Evidence from France". www. Ssrn.com.

[27] McMulen, D. A. (1996). "Audit committee performance: an investigation of the consequences associated with audit committee", Auditing, Vol. 15 (1): pp. 87-103.

[28] McNally, G. M., L. H. Eng, et al. (1982). "Corporate financial reporting in New Zealand: An analysis of user preferences, corporate characteristics and disclosure practices for discretionary information". Accounting and Business Research, Vol. 12(46): pp. 11-20.

[29] Meek, G. K., C. B. Roberts, et al. (1995). “Factors influencing voluntary annual report disclosure U.S., U.K., and continental European multinational corporations".Journal of International Business Studies, Vol.26(3): pp. 5-572.

[30] Mora, A và W. Rees (1996). “The early adoption of consolidated accounting in Spain".Eupropean Accounting Review, Vol. 7: pp. 675-696.

[31] Newman, P. và R. Sansing (1993). "Disclosure policies with multiple uses". Journal of Accounting Research, Vol. 31(1): pp. 92-112.

[32]Nguyen Cong Phuong and Nguyen ThiThanh Phuong (2014)."Factors affecting the disclosure of financial information". Vietnamese Journal of Economic Development, No. 287 (9/2014), 15-33

[33] Owusu-Ansah, S. (1998). "The impact of corporate attributes on the extent of mandatory disclosure and reporting by listed companies in Zimbabwe". The International Journal of Accounting Vol. 33(5): pp. 605-631.

[34]Patton, J. và I. Zelenka (1997)."An empirical analysis of the determinants of the extent of disclosure in annual reports of joint stock companies in the Czech Republic." European Accounting Review Vol. 6(4): pp. 605-626.

[35] Raffournier, B. (1995). "The determinants of voluntary financial Disclosure by Swiss listed companies". European Accounting Review, Vol. 4:pp. 261-280.

[36] Singhvi, S. S. (1968). "Characteristics and implication of inadequate disclosure: A case study of India".The international journal ofAccounting, Vol. 3(2): pp. 29-44.

[37] Singhvi, S. S. và H. B. Desai (1971). “An empirical analysis of quality of corporate financial disclosure". The Accounting Review , Vol. 129138.

[38] Tabachnick, B. G. vàFidell, L. S ( 1996). "Using Multivariate Statistics".Haper Collins College Publishers.

[39] Urquiza, F. B., M. C. Abad Navarro, et al. (2009). "Disclosure indices design: does it make a difference?"Revista de contabilidad Vol. 12(2): pp 253-277.

[40] Wang, K., O. Sewon, et al. (2008). "Determinants and consequences of voluntary disclosure in an emerging market: Evidence from China". Journal of International Accounting, Auditing and Taxation Vol. 17(1): pp 14-30.

[41] Watts, R. L. và J. L. Zimmerman, Eds. (1990). "Positive Accounting Theory: a ten year perspective”. Prentice-Hall. London.

[42] Wallace, R .S. và K. Naser (1994). "Firm specific determinants of comprehensive of mandatory disclosure in the corporate annual reports of firms listed on the stock exchange of Hong Kong”. Journal ofAccounting \& Public Policy, Vol. 14: pp. 31-68.

[43] Van Greuning, H., Scott, D., \&Terblanche, S. (2011). "International financial reporting standards: a practical guide”. World Bank Publications.

[44] Yuan Dinh, Linghui Fu, et al. (2006). "Disclosure and determinants studies: An extension using the divisiveclustering method (DIV)". European Accounting Review, Vol. 15, No. 2,pp. 181-218. 